\title{
Foraging habitat selection by Little Terns Sternula albifrons in an estuarine lagoon system of southern Portugal
}

\author{
VITOR H. PAIVA, ${ }^{1 *}$ JAIME A. RAMOS,${ }^{1}$ JORGE MARTINS,${ }^{2}$ ANA ALMEIDA ${ }^{2}$ \& ANA CARVALHO ${ }^{1}$ \\ ${ }^{1}$ IMAR-Instituto do Mar, Department of Zoology, University of Coimbra, 3004-517 Coimbra, Portugal \\ ${ }^{2}$ CCMAR-Centro de Ciências do Mar - Coastal Fisheries Research Group, University of the Algarve, 8000 Faro, Portugal
}

\begin{abstract}
We assessed the effects of environmental variables on the distribution and feeding behaviour of adult Little Terns Sternula albifrons in Ria Formosa Natural Park, Algarve, southern Portugal, in different foraging habitats (main lagoon, salinas and sea) during the breeding seasons, April-July, of 2003-05. Foraging density was higher in the lagoon than in the sea, and at low tide. The number of foraging individuals at sea was independent of tide. Individual Little Terns foraged further from the nearest breeding colony in April and May (courtship feeding and incubation) than in June and July (chick-rearing). During intermediate tidal phases, individuals foraged further from the nearest colony, and followed main lagoon channels, perhaps because stronger currents increased prey availability. Diving activity and foraging success were higher in 2003 than 2004 or 2005, perhaps because of greater availability of marine prey in 2003. Diving rate was higher in July (when independent juveniles began learning how to forage) but diving success was higher in June (chick-rearing) than in other months. The variables selected by the final logistic models reflected four basic needs for the selection of feeding habitats by Little Terns: (1) association between foraging individuals, (2) areas with abundant feeding resources, (3) entrance channels and main lagoon channels with strong currents, and (4) the proximity to areas with alternative feeding resources, the salinas. Areas subjected to strong human pressure were avoided by foraging Little Terns.
\end{abstract}

Keywords: estuaries, foraging habitat selection, Geographical Information Systems, Little Tern, logistic regression, prey distribution [Keywords added after online publication 7 June 2007].

Seabirds are predictably associated with a wide range of physical features of the marine environment, such as water masses (identified from gradients of temperature and salinity; Montevecchi \& Myers 1996), ecosystem gradients, coastline and topographical patterns (reviewed by Schneider 1991, Garthe 1997, Hunt 1997). Many studies assume that these characteristics promote an increase in the abundance and availability of prey (Ballance et al. 2001, Vlietstra et al. 2005). Estuarine seabird species such as the Little Tern Sternula albifrons are highly susceptible to changes in food availability, in particular during the breeding season, as they forage mostly within $4 \mathrm{~km}$ of their colonies (Fasola \& Bogliani 1990, Allcorn et al. 2003). The choice of nesting sites close to good foraging resources allows individuals to minimize travel time

${ }^{*}$ Corresponding author.

Email: vitorpaiva@ci.uc.pt and energy expenditure, and thereby to allocate a greater proportion of time and energy to their nestling's needs. Therefore, more distant foraging sites may be used if they are particularly profitable in terms of greater availability, nutritional or energy value of prey (Stienen et al. 2000), or suitability of prey size and type for different needs of growing chicks (Wendeln 1997, Lyons et al. 2005).

Breeding habitat selection of coastal tern species is well known (Burger \& Lesser 1978, Kotliar \& Burger 1986, Smith \& Renken 1991, Ramos \& del Nevo 1995, Ramos 1998, Krogh \& Schweitzer 1999, Medeiros et al. 2007), but there is much less information on foraging habitat selection. Factors such as wind speed, tidal phase and foraging range are known to influence the feeding ecology of terns (Dunn 1973, Cramp \& Simmons 1983, Hulsman et al. 1989, Becker \& Specht 1991, Frank \& Becker 1992, Frank 1992, Becker et al. 1993, Brenninkmeijer et al. 2002). It is known that 
stronger winds may reduce adult body mass (Frank \& Becker 1992) and chick food provisioning (Paiva et al. 2006a). Several studies have described a pattern of coastal tern species feeding mainly during incoming and/or receding tides (Hulsman 1977, Smith 1990, Taylor 1997), when schools of juvenile fish enter estuaries to the main lagoon channels, where currents are stronger than in secondary channels. The entrance channels to water-bodies such as lakes and lagoons were also reported as important feeding sites (Taylor $\&$ Roe 2004). Therefore, main channels and entrance channels of lagoons should attract flocks of feeding birds such as terns (Erwin 1978).

The diet of many tern species (Fraser 1997, Ramos et al. 1998, McGinnis \& Emslie 2001, Nisbet 2002), including Little Terns (Fasola \& Bogliani 1990, Taylor \& Roe 2004, Catry et al. 2006, Paiva et al. 2006a, 2006b), has been quite well studied but the relationship between the occurrence of foraging Little Terns and the factors that influence the availability of their estuarine and marine prey has received little attention (Catry et al. 2006, Paiva et al. 2006a). Models of foraging habitat selection and their spatial representation with a Geographical Information System (GIS) can help to understand the reasons driving the selection of foraging areas and obtain probabilistic models of the foraging distribution of this species (Huettmann \& Diamond 2001). These will be important when implementing conservation measures because Little Terns are estuarine birds that use coastal areas heavily used by humans. This paper reports on the foraging ecology and habitat selection of feeding Little Terns in Ria Formosa, a lagoon system in the Algarve, southern Portugal, during the mating, incubation and chick-rearing periods. In this area the birds have different choices of foraging habitats: lagoon, entrance channels, adjacent sea, salinas and adjacent channels. This study describes the distribution of foraging Little Tern adults during the breeding season in different habitats and tidal phases, and assesses which environmental variables influence the selection of feeding areas within the main lagoon and adjacent habitats. The probability of occurrence of foraging Little Terns in Ria Formosa is mapped using GIS in order to aid the application of conservation measures.

\section{METHODS}

\section{Study area}

Ria Formosa Natural Park is situated on the south coast of Portugal, Algarve $\left(37^{\circ} 01^{\prime} \mathrm{N}, 07^{\circ} 48^{\prime} \mathrm{W}\right)$, and consists of a complex tidal system of natural/semi-natural channels (lagoon), marshland and barrier-islands covering an area of 18400 ha along $60 \mathrm{~km}$ of coast. In the margins of the marshland area, there are artificial salt-pans (salinas) and extensive fish farms. Close to the Park's northern borders, there are three large towns: Faro, Olhão and Tavira. Faro has a commercial port and Olhão and Tavira have fishing ports.

Our observations took place in two areas of the park: (1) Faro-Olhão, within main and secondary channels that flow close to the barrier-island of Barreta and Ancão peninsula, and (2) Tavira, along the main channels, sandy beaches and salinas surrounding the barrier-islands of Armona and Tavira (Fig. 1). In both areas, Little Terns breed on sandy beaches and in artificial salt-pans (salinas; Catry et al. 2004).

\section{Foraging in relation to habitat and tide}

Between 2003 and 2005 a total of 260 visits to six transect routes (hereafter called transects) were made on foot during the breeding period (from April to July) to cover the main Little Tern foraging habitats, on Ancão peninsula and Barreta barrier-island (lagoon: $\operatorname{Tr} 1-\operatorname{Tr} 4$ in 2004), Armona barrier-island (sea and lagoon: $\operatorname{Tr} 5$ in 2003-05) and Santa Luzia salinas (lagoon and salinas: Tr8 in 2003-05, Fig. 1). In 2004, 18 boat visits were made to two transects within the lagoon area close to Faro to cover main and secondary channels in the inner lagoon (RI and RII transects, Fig. 1). For each visit to a whole transect route (i.e. our sampling unit), we recorded the number of foraging adults per habitat type (sea, lagoon and salinas) during each tidal phase (low, high, incoming and receding). We considered that each tidal phase lasted $3 \mathrm{~h} \mathrm{(1.5} \mathrm{h}$ before and after each tide peak). In 2004, transects $\operatorname{Tr} 1-\operatorname{Tr} 4$ were walked every month from April to June during each tidal phase, in order to examine seasonal variations in the abundance of foraging terns.

\section{Focal sampling of feeding behaviour}

Between 2003 and 2005, 456 foraging individuals were located along transects and opportunistically on the peninsula of Ancão, Barreta, Tavira, Armona and the salinas of Ramalhete (near Faro) and Sta. Luzia (near Tavira). Each individual was observed for at least $60 \mathrm{~s}$ on one of three different habitats: sea, main lagoon channels and salinas. For each individual we recorded the number of dives per minute (foraging effort) and the number of prey captured per minute (foraging success) in relation to tidal phase. 

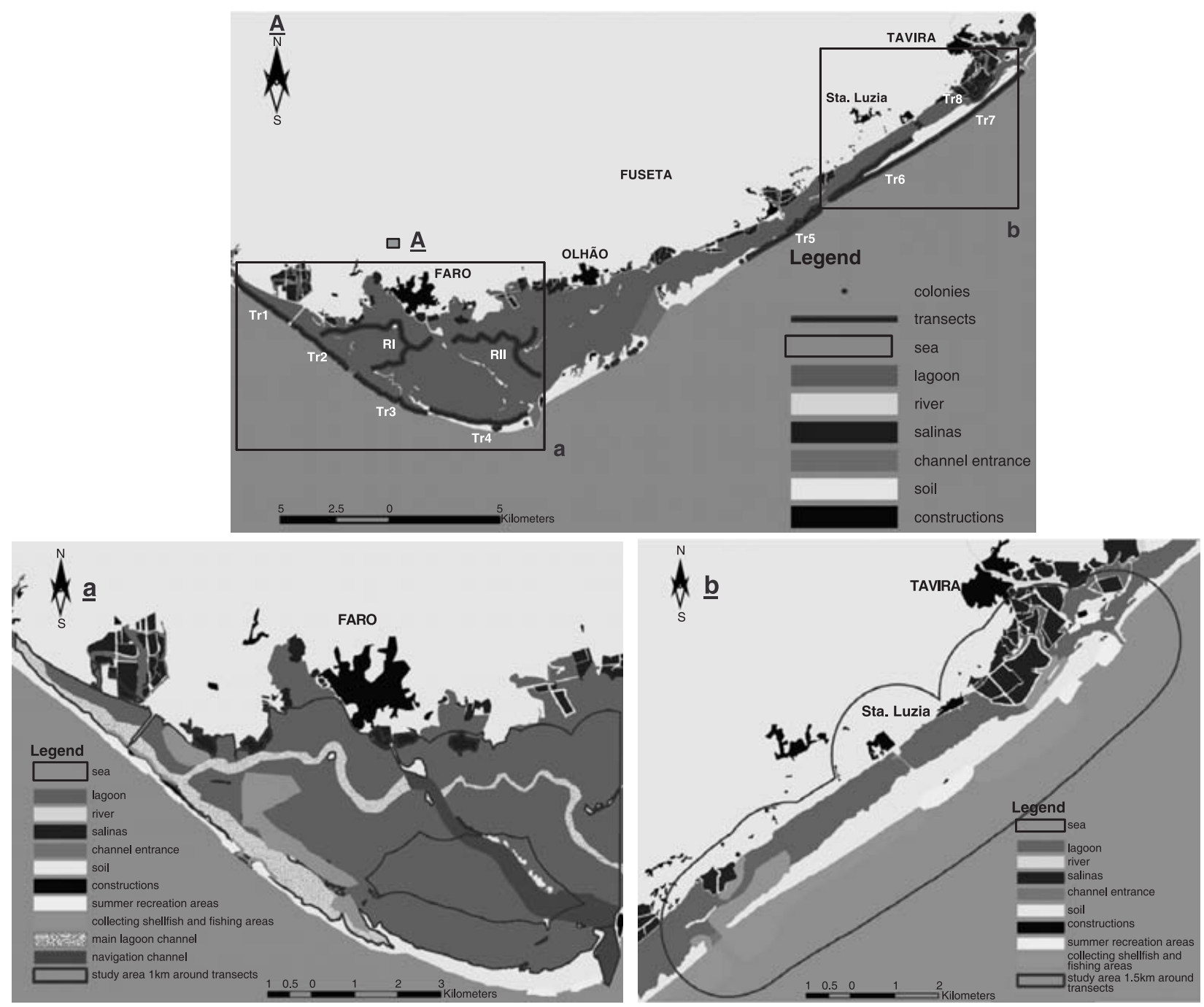

Figure 1. General view of the study area of Ria Formosa Natural Park, showing the different habitat types in the area and main towns (A). The insets show a detailed view of the two study areas: the inner lagoon (a, area I model) in front of Faro and a mixed area of salinas, lagoon and adjacent sea (b, area II model).

\section{Modelling foraging habitat selection}

We adopted the same modelling approach for two foraging areas: an area of inner lagoon (Area I model) and a mixed area of lagoon, salinas and adjacent sea (Area II model, Fig. 1). For the Area I model we used the position of foraging Little Terns recorded on 170 transect visits in $2004(\operatorname{Tr} 1-\operatorname{Tr} 4, \mathrm{R} 1$ and R2). For the Area II model we made 128 transect visits to three transects in 2005, along the main channels, sandy beaches and salinas surrounding the barrier-island of Tavira (Tr6-Tr8) to locate the position of foraging individuals in the sea, lagoon or salinas. These transects were a subset of those used to measure foraging as a function of habitat and tide. For each sighting we registered the number of foraging individuals per habitat type (sea, lagoon and salinas), the geographical position using a GPS (Global Positioning System) and, for individuals at sea, we estimated the distance to the seashore. Birds were recorded in square units of $100 \times 100 \mathrm{~m}$ for both models. This effort resulted in 194 squares with Little Terns for the Area I model and 248 squares with Little Terns for the Area II model. To analyse the habitat characteristics that may influence the occurrence of feeding Little Terns we selected the same number of random squares without foraging individuals (Jones 2001) for each model. Squares with and without birds were selected 
Table 1. Independent variables used in the foraging habitat selection study at Ria Formosa, Algarve, Portugal. These variables were measured on a grid of $100 \times 100-\mathrm{m}$ squares, within 1 and $1.5 \mathrm{~km}$ radius around transects for the Area I and Area II models, respectively. Distances were measured from the centre of each square.

\begin{tabular}{|c|c|c|c|}
\hline Variable & Description & Units & Code \\
\hline Habitat & Sea, lagoon, salinas or entrance channel & $1-4$ & HABI \\
\hline Foraging terns & $\begin{array}{l}\text { Presence of other foraging individuals on } \\
\text { adjacent selected squares }\end{array}$ & $0 / 1$ & TERN \\
\hline Shellfish collecting activities & Presence of shellfish collecting or fishing activities & $0 / 1$ & ACTI \\
\hline Summer recreation areas & Presence of human summer recreation areas & $0 / 1$ & SUMM \\
\hline Sea† & Presence of sea & $0 / 1$ & SEA \\
\hline Lagoon & Presence of lagoon & $0 / 1$ & LAGO \\
\hline Salinas & Presence of salinas tanks & $0 / 1$ & SALI \\
\hline Entrance channel & Presence of entrance channel & $0 / 1$ & ENTR \\
\hline Seashore† & Presence of seashore & $0 / 1$ & SAES \\
\hline Main lagoon channels* & Presence of main lagoon channels & $0 / 1$ & MAIN \\
\hline Navigation channel $^{*}$ & Presence of navigation channel & $0 / 1$ & NAVI \\
\hline$\%$ Habitat & Percentage of the four habitats on each square & $\%$ & PHAB \\
\hline$\%$ Soil & Percentage of soil on each square & $\%$ & PSOI \\
\hline Distance to buildings & Distance to the nearest construction ( $>5$ buildings) & $\mathrm{m}$ & DCON \\
\hline Distance to colony & Distance to the nearest colony & $\mathrm{m}$ & DCOL \\
\hline Distance to entrance channel & Distance to the nearest entrance channel & $\mathrm{m}$ & DENT \\
\hline Distance to lagoon & Distance to the nearest lagoon area (main channel) & $\mathrm{m}$ & DLAG \\
\hline Distance to sea & Distance to the nearest sea area & $\mathrm{m}$ & DSEA \\
\hline Distance to salinas & Distance to the nearest salinas salt tanks & $\mathrm{m}$ & DSAL \\
\hline Distance to river & Distance to the nearest river/stream & $\mathrm{m}$ & DRIV \\
\hline Distance to seashore & Distance to the nearest coastline & $\mathrm{m}$ & DSES \\
\hline Distance to summer recreation areas & $\begin{array}{l}\text { Distance to the nearest high human summer } \\
\text { recreation areas, observed between } 2003 \text { and } 2005\end{array}$ & $\mathrm{~m}$ & DSUM \\
\hline Distance to harvesting shellfish area & $\begin{array}{l}\text { Distance to the nearest harvesting shellfish or } \\
\text { fishing area, observed between } 2003 \text { and } 2005\end{array}$ & $\mathrm{~m}$ & DACT \\
\hline Distance to main lagoon channels* & Distance to the nearest main lagoon channels & $\mathrm{m}$ & DMAI \\
\hline Distance to navigation channel ${ }^{*}$ & Distance to the nearest navigation channel & $\mathrm{m}$ & DNAV \\
\hline Distance to selected square & Distance to the nearest selected square & $\mathrm{m}$ & DSEL \\
\hline Distance to non-selected square & Distance to the nearest nonselected square & $\mathrm{m}$ & DNSE \\
\hline
\end{tabular}

*Only applied to the Area I model.

†Only applied to the Area II model.

within a radius of $1 \mathrm{~km}$ around transects $\operatorname{Tr} 1-\operatorname{Tr} 4, \mathrm{R} 1$ and R2 (based on visibility limited by vegetation at low tide, for R1 and R2 transects). To select squares for the Area II model, a radius of $1.5 \mathrm{~km}$ around transects $\operatorname{Tr} 6-\operatorname{Tr} 8$ (with good visibility from Tavira barrier-island to the open sea) was considered. We modelled the influence of 29 independent variables (Table 1) on presence (1) or absence (0) of feeding adults (dependent variable) using logistic regression models. The squares without birds were obtained randomly using the extension random point generator (randpts.avx; Jenness 2005a) for ArcView v3.x. To obtain the distances from the middle of each square to the limits of the different variable polygons, we used the extension nearest features (nearfeat.avx; Jenness 2005b) also for ArcView v3.x.

\section{Data analysis}

Foraging in relation to habitat and tide

Data were checked for normality (KolmogorovSmirnov test) and homoscedasticity (Levene's test). Number of feeding adults per transect was log transformed $(\log (x+1))$ to meet assumptions of normality and homoscedasticity of variances. A General Linear Model (with Poisson error distribution) considering transect route as a fixed effect, followed by Tukey test for unequal $n$, was used to assess the effects of habitat (sea, lagoon, salinas), tidal state (low, high, incoming and receding) and year $(2003,2004,2005)$ on the number of foraging adults per transect (each sampling unit was one visit to a whole transect route). For this analysis we used only transect $\operatorname{Tr} 5$ and $\operatorname{Tr} 8$ 
Table 2. Logistic regression univariate analysis showing the relationship between each independent variable with the occurrence (presence/absence) of Little Tern foraging adults. Variables with an important influence $(P<0.25)$ are shown in bold type.

\begin{tabular}{|c|c|c|c|c|c|c|c|}
\hline \multicolumn{3}{|c|}{ Area I model } & \multirow[b]{2}{*}{$P$} & \multicolumn{3}{|c|}{ Area II model } & \multirow[b]{2}{*}{$P$} \\
\hline $\begin{array}{l}\text { Variables } \\
\text { (Code) }\end{array}$ & $\begin{array}{l}\text { Relation with the } \\
\text { dependent variable }\end{array}$ & Wald test & & $\begin{array}{l}\text { Variables } \\
\text { (Code) }\end{array}$ & $\begin{array}{l}\text { Relation with the } \\
\text { dependent variable }\end{array}$ & Wald test & \\
\hline $\mathrm{HABI}^{+}$ & + & 0.84 & 0.36 & $\mathrm{HABI}^{+}$ & + & 23.19 & 0.00 \\
\hline $\mathrm{PHAB}^{+}$ & - & 0.12 & 0.72 & $\mathrm{PHAB}^{+}$ & + & 6.13 & 0.01 \\
\hline $\mathrm{PSOI}^{+}$ & + & 0.12 & 0.72 & $\mathrm{PSOI}^{+}$ & - & 6.13 & 0.01 \\
\hline TERN & + & 151.73 & 0.00 & TERN & + & 62.27 & 0.00 \\
\hline $\mathrm{DCON}^{+}$ & - & 27.13 & 0.00 & DCON & + & 33.80 & 0.00 \\
\hline $\mathrm{DCOL}^{+}$ & - & 42.35 & 0.00 & $\mathrm{DCOL}$ & - & 27.83 & 0.00 \\
\hline ENTR & - & 0.98 & 0.32 & ENTR & + & 2.49 & 0.11 \\
\hline $\mathrm{DENT}^{+}$ & - & 22.38 & 0.00 & DENT & - & 19.96 & 0.00 \\
\hline LAGO & - & 3.47 & 0.06 & LAGO & + & 5.13 & 0.02 \\
\hline DSEA $^{+}$ & - & 65.74 & 0.00 & DLAG & - & 19.94 & 0.02 \\
\hline SALI $^{*}$ & & & & SEA & + & 0.52 & 0.47 \\
\hline $\mathrm{DSAL}^{+}$ & + & 19.55 & 0.00 & DSEA & - & 29.58 & 0.00 \\
\hline $\mathrm{DRIV}^{+}$ & + & 37.90 & 0.00 & SALI & - & 20.10 & 0.00 \\
\hline SUMM & - & 5.45 & 0.02 & DSAL & - & 43.83 & 0.00 \\
\hline DSUM $^{+}$ & - & 53.63 & 0.00 & DRIV & - & 28.84 & 0.00 \\
\hline $\mathrm{ACTI}$ & - & 10.44 & 0.00 & SEAS & + & 0.57 & 0.45 \\
\hline $\mathrm{DACT}^{+}$ & - & 32.33 & 0.00 & DCOA & - & 15.25 & 0.00 \\
\hline NAVI & + & 1.89 & 0.17 & SUMM & + & 2.56 & 0.11 \\
\hline $\mathrm{DNAV}^{+}$ & + & 29.41 & 0.00 & DSUM & - & 61.28 & 0.00 \\
\hline MAIN & - & 140.58 & 0.00 & ACTI & + & 118.66 & 0.00 \\
\hline $\mathrm{DMAl}^{+}$ & - & 138.67 & 0.00 & DACT & - & 119.41 & 0.00 \\
\hline
\end{tabular}

*The model could not be adjusted because of empty cells on the crosstabs tables.

${ }^{+}$Categorical variables.

because these were walked in May-June of each year. Transect route was entered as a fixed effect in the model. The categories '2004' and 'salinas' were removed from the analysis, because of small sample size ( $n=25$ and 9 for '2004' and 'salinas', respectively).

We computed the distance of each sighted individual to the nearest breeding colony using data from transects $\operatorname{Tr} 1-\operatorname{Tr} 4(\operatorname{Tr} 6-\operatorname{Tr} 8$ were not used because in 200304 the geographical position system of the birds was not obtained). Differences in the distance of sighted foraging birds to the nearest colony among months (April, May, June and July) and tidal state (low, high, receding and incoming) were tested using a two-way ANOVA followed by a post-hoc Tukey test for unequal $n$.

\section{Focal sampling of feeding behaviour}

Assumptions of normality and homocedasticity were not met for measures of foraging effort (number of dives/min) and foraging success (number of prey/min). Therefore, we assessed differences in foraging success and effort among months (May, June and July), habitats (lagoon, sea and salinas) and tidal states (low, high, incoming and receding) with a Kruskal-Wallis $H$-test followed by a post-hoc Nemenyi test.

\section{Modelling foraging habitat selection}

Following Hosmer and Lemeshow (2000), model construction began with an exploratory analysis of all independent variables. For categorical and dichotomous variables, we eliminated categories with empty cells (Hosmer \& Lemeshow 2000, Manel et al. 2001). Categorical variables were entered using the reference cell coding methodology, with the first quartile as the reference, and continuous variables were categorized using the design variable method described by Hosmer and Lemeshow (2000).

First, a univariate analysis was performed, to measure the association of each of the 29 independent variables with the response variable, using the Wald test (Hosmer \& Lemeshow 2000, Franco \& Sutherland 2004). Any variable with a Wald test value of $P<0.25$ was a candidate for the multivariate model (Table 2; Hosmer \& Lemeshow 2000). Secondly, a Spearman correlation matrix was generated to check for 
collinearity between variables (Zar 1999, Dytham 2003). For pairs of variables that were highly correlated $\left(r_{\mathrm{s}}>0.7\right.$; Tabachnick \& Fidell 1996, Hosmer \& Lemeshow 2000) the variable with the higher $P$ value was excluded: (1) for the Area I model DRIV, DCOL, DSEA, DACT, DNAV and DSUM were excluded because they were highly correlated with DSES, DENT, DMAI; (2) for the Area II model DLAG, HABI, DSAL and ACTI were also excluded due to the high correlation with DSES, DSUM, DCON and DCOL (Table 1).

To build the multivariate model we first entered all variables selected from the univariate analyses. Because our aim was to obtain the best fitting model minimizing the number of variables, we then fitted a reduced model containing only the significant variables, i.e. those with $P<0.05$ using the Wald test. We compared the two models with a likelihood ratio test (G-statistic) and concluded that the reduced model was as good as the full model (Hosmer \& Lemeshow 2000). Next, possible meaningful interactions between variables were searched. The excluded biological meaningful variables and interactions between them were tested once more, using both the Wald statistic for each variable and the likelihood ratio test between models, before obtaining the final model. Only those variables (and interactions) that increased their Wald test value and the G-test value for the significance of the model were retained in the multivariate model (Hosmer \& Lemeshow 2000).

To assess the fit of each model we used a G-test, a Hosmer-Lemeshow test and a contingency table (using a cut-point of 0.50 to explain a similar percentage of correct classifications of both Little Tern presences and absences). The area under the receiver operating characteristics (AUC or area under the ROC (Zweig \& Campbell 1993, Osborne et al. 2001)) was also analysed. This curve compares the sensitivity (proportion of correct classification of squares with absences on the $y$-axis) with the specificity (proportion of incorrect classification of squares with presences on the $x$-axis), with values above 0.5 indicating a significant discrimination for the model (Pardo \& Ruiz 2002, Pinilla 2002). Finally, we inspected the data points that had a lesser or higher influence on the models, using Cook's distance, leverage values and standardized residuals (Hosmer \& Lemeshow 2000).

From the final models, the $\beta$ coefficients and the odds ratio were analysed, in order to understand the relationship between each independent variable and the presence or absence of foraging Little Terns (Hosmer \& Lemeshow 2000). Mapped visualization of models was obtained using a GIS package ArcView v3.3 and ArcGIS v8.3 (ESRI 2004) that allowed the combination of several layers corresponding to the variables selected by the model. The final output was a map with the probability of occurrence of Little Terns throughout the study area together with a layer showing actual presences of Little Terns (Franco et al. 2000, Franco \& Sutherland 2004).

All statistical analyses were carried out with STATISTICA v6.0 (Statsoft 1996) and SPSS v13 (Field 2000), and the significance level was set at $P<0.05$. In relation to the spatial analysis of data, measure of variables and visualization of the final logistic model we used the GIS package - ArcView v3.3 and ArcGIS v9.0 (ESRI 2004). All data are presented as mean \pm se, unless stated otherwise.

\section{RESULTS}

\section{Foraging in relation to habitat and tide}

The mean number of foraging individuals per transect was significantly higher in the lagoon than in the sea $\left(F_{1,176}=14.82, P<0.01\right)$, significantly higher during low tide than during the other tidal phases $\left(F_{3,176}=\right.$ $5.89, P<0.001)$, both at sea and in the lagoon, and also on transect route no. 8 in relation to no. $5\left(F_{1,176}=\right.$ $5.25, P<0.05)$. There was a significant interaction between habitat and tidal phase $\left(F_{3,176}=5.27, P<\right.$ 0.01 ; Fig. 2), with tidal effects (more birds at low and incoming tides) only apparent in the lagoon. During the three study years, 125 transect visits were made to the salinas, but only nine foraging individuals were recorded there.

The distance of foraging Little Terns to the nearest breeding colony varied monthly (April-July): individuals were sighted significantly further from the nearest colony in April and May than in June and July $\left(F_{3,242}=9.44, P<0.01\right.$, Fig. 3$)$. By contrast, tidal phase had no effect on foraging distance from the nearest colony $\left(F_{3,242}=2.15, P=0.09\right.$; Fig. 3$)$. Although mean flock sizes $( \pm \mathrm{sd})$ of $1.25 \pm 0.78(n=83)$ in the lagoon and $1.53 \pm 1.3(n=40)$ in the sea were small, flocks with 45 individuals were sighted over the sea twice.

\section{Feeding behaviour}

Little Terns had a greater diving activity $\left(H_{2,456}=\right.$ $21.91, P<0.01$ ) and success (prey/min; $H_{2,456}=9.46$, $P<0.05)$ in 2003 than in the other study years. Seasonally, adults dived significantly more $\left(H_{2,456}=\right.$ 

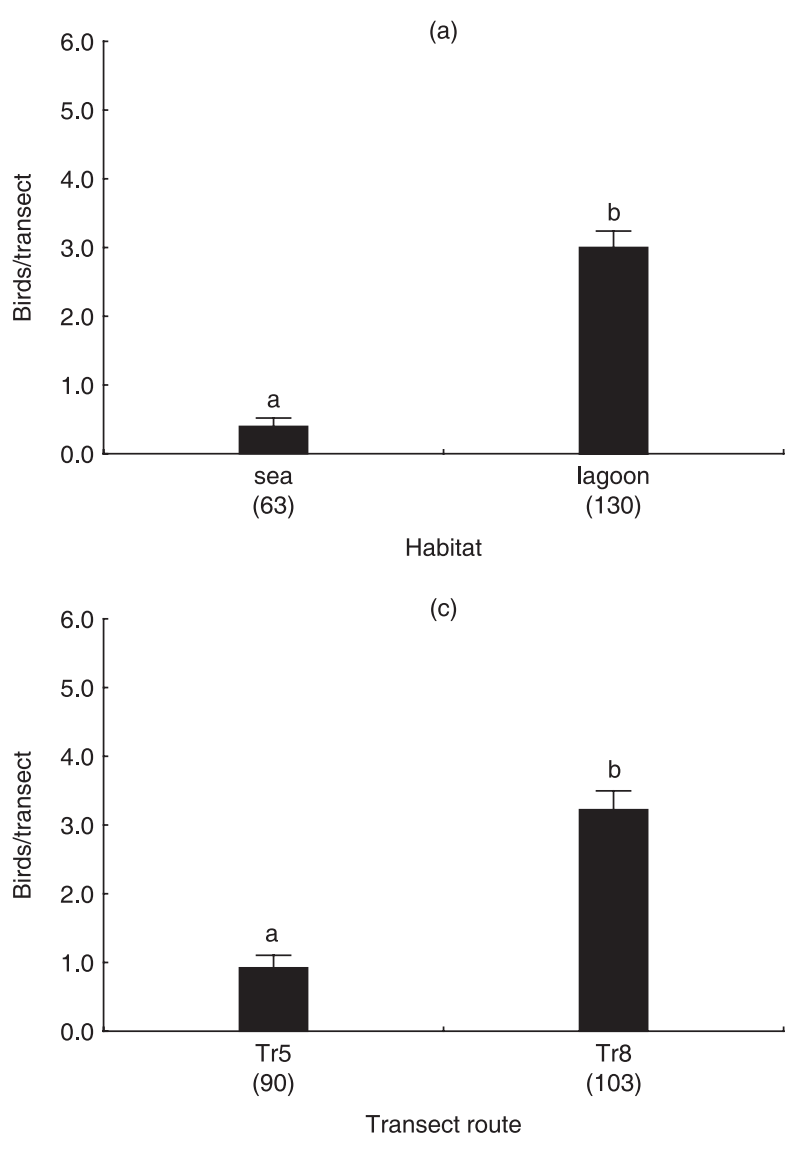
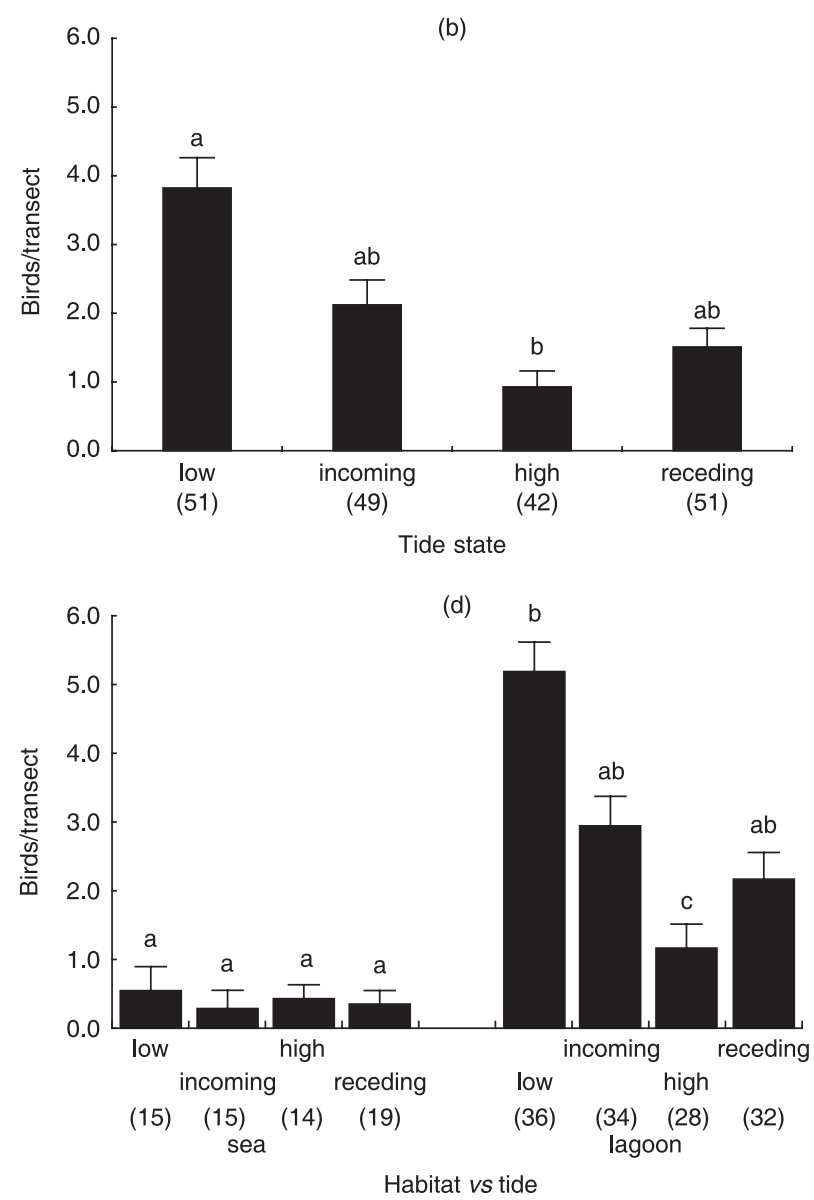

Figure 2. Mean number of foraging adults per transect (mean \pm se, with sample sizes in parentheses) in relation to habitat (a), tide state (b), transect route (c) and interaction between habitat and tide (d). Different lower-case letters indicate significant differences in the number of birds per transect (General Linear Model with Poisson error distribution considering transect route as a fixed effect, followed by post-hoc Tukey test for unequal $n$ with $P<0.05)$.

14.52, $P<0.01)$ in July but had higher success $\left(H_{2,456}=22.98, P<0.01\right)$ in June than in the other months. In addition, on the sea adults had less diving activity $\left(H_{2,456}=8.05, P<0.05\right)$ and also reduced capture success $\left(H_{2,456}=26.30, P<0.01\right)$. Finally, there were no significant differences in the number of dives/min $\left(H_{3,456}=5.78, P=0.12\right)$ and prey captured $/ \mathrm{min}\left(H_{3,456}=2.41, P=0.49\right.$; Fig. 4$)$ among tidal phases.

\section{Feeding habitat selection}

\section{Area I model - inner lagoon}

The univariate analysis selected 18 independent variables to explain habitat selection within inner lagoon areas by Little Terns (Table 2). In the multivariate model, the variables TERN, MAIN, DENT and DSAL were selected as important explanatory variables. The presence of feeding adults was positively related to the presence of other feeding individuals on adjacent selected squares (TERN) and to proximity to salinas (DSAL 1). Little Terns were more likely to be found in association with main lagoon channels (MAIN) and close to the entrance channels (where breeding colonies were located; DENT 1-3, Table 3). The probability of occurrence of feeding adults was 30 times higher in squares adjacent to other squares oocupied by Terns than those adjacent to unoccupied squares, 20 times higher in the main channel than secondary channels, and higher closer to entrance channels and salinas (Table 3). The Area I model was well adjusted to the observed data, with a good capacity to explain the probability of occurrence of foraging individuals $(G=124.18, P=0.00)$, and 

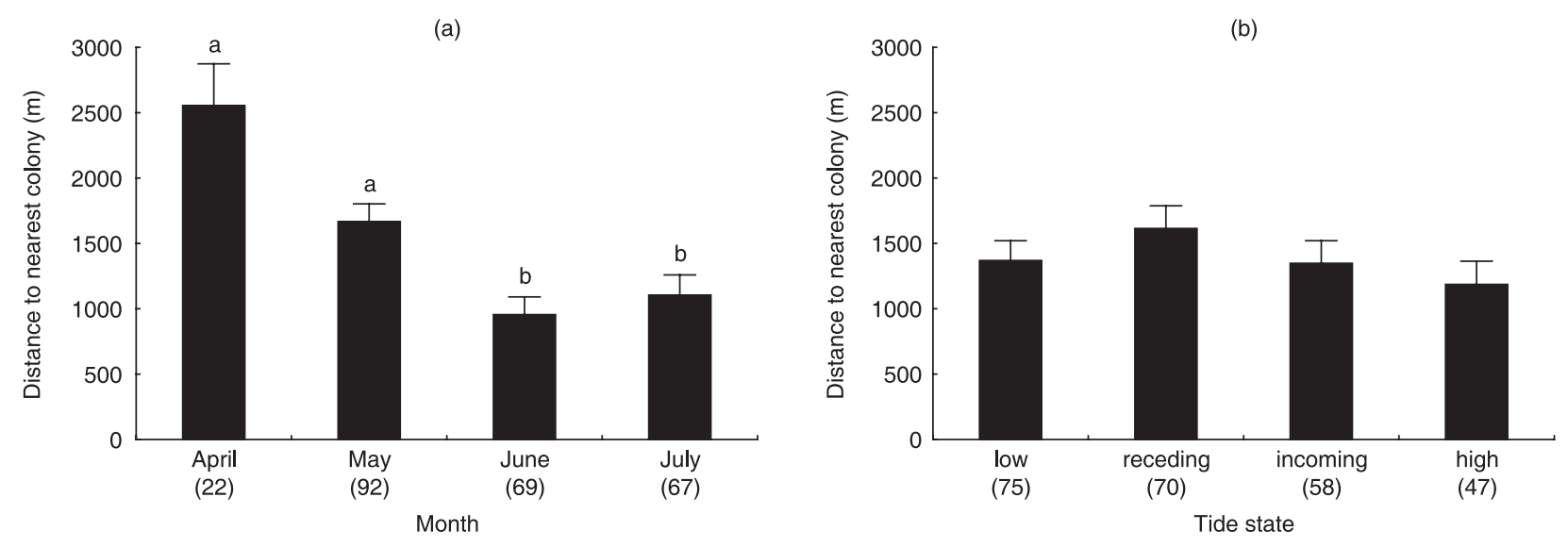

Figure 3. Distance of feeding birds to colonies in relation to month (a) and tide state (b) on the peninsula of Ancão and barrier-island of Barreta in 2004 (mean \pm se with sample sizes in parentheses). Different lower-case letters indicate significant differences in number of birds per transect (two-way ANOva followed by post-hoc Tukey test for unequal $n$ at $P<0.05$ ).
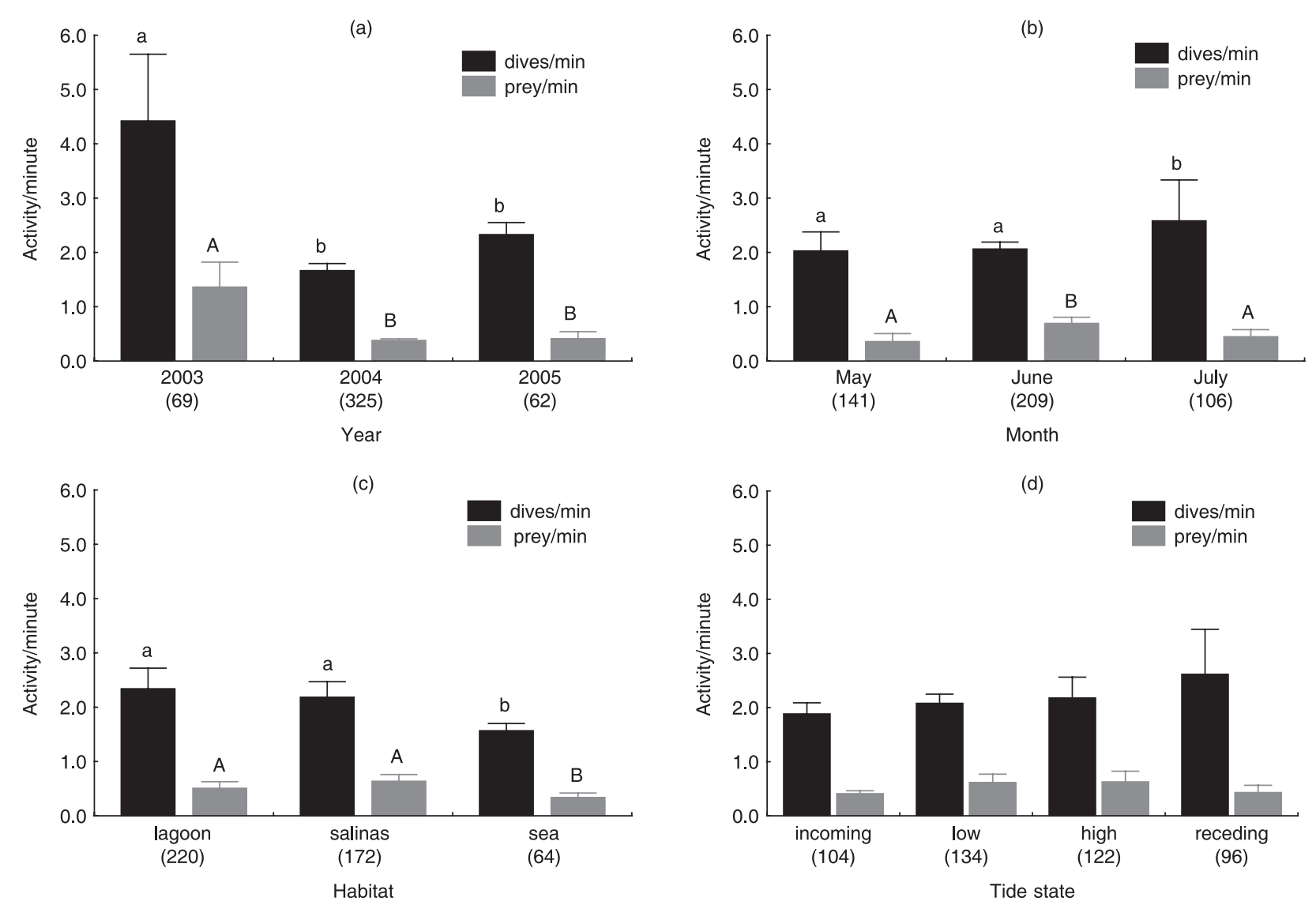

Figure 4. Foraging effort and capture success (mean $\pm s e$, with number of observations in parentheses) of adult Little Terns in relation to year (a), month (b), foraging habitat (c) and tide state (d). Different lower-case letters indicate significant differences for dives/min and different upper-case letters indicate significant differences for prey/min (Kruskal-Wallis $H$-test followed by post-hoc Nemenyi test). 
Table 3. Area I model: inner lagoon habitat. Coefficients $(\beta)$, standard errors (se), significance value $(P)$ and odds ratio $(\mathrm{OR})$ for each selected variable are presented.

\begin{tabular}{|c|c|c|c|c|c|}
\hline Variable & $\beta \pm$ se & Wald test & $d f$ & $P$ & OR \\
\hline Foraging terns (TERN) & $3.39 \pm 0.39$ & 75.98 & 1 & 0.00 & 29.83 \\
\hline Absence of main lagoon channels (MAIN) & $-2.90 \pm 0.39$ & 55.44 & 1 & 0.00 & 0.05 \\
\hline Distance to entrance channel (DENT) $\dagger$ & & 18.12 & 3 & 0.00 & \\
\hline 1349-2423 m (DENT 1) & $-0.95 \pm 0.57$ & 2.74 & 1 & 0.10 & 0.39 \\
\hline 2424-3379 m (DENT 2) & $-2.51 \pm 0.51$ & 16.76 & 1 & 0.00 & 0.08 \\
\hline 3380-6491 m (DENT 3) & $-1.89 \pm 0.59$ & 10.28 & 1 & 0.00 & 0.15 \\
\hline Distance to salinas (DSAL) $\ddagger$ & & 8.54 & 3 & 0.04 & \\
\hline 705-1233 m (DSAL 1) & $1.37 \pm 0.57$ & 5.78 & 1 & 0.02 & 3.94 \\
\hline 1234-2520 m (DSAL 2) & $0.69 \pm 0.55$ & 1.57 & 1 & 0.21 & 2.00 \\
\hline 2521-5451 m (DSAL 3) & $-0.18 \pm 0.61$ & 0.08 & 1 & 0.77 & 0.84 \\
\hline Constant & $0.46 \pm 0.70$ & 0.44 & 1 & 0.50 & 1.59 \\
\hline Likelihood ratio test & $G=124.18, d f=9, P=0.00$ & & & & \\
\hline Area Under the ROC (AUC) & Area $=0.95^{\star} \pm 0.01, P=0.00$ & & & & \\
\hline Hosmer \& Lemeshow test & $\chi^{2}=7.03, d f=8, P=0.53$ & & & & \\
\hline Correct classification & of presences & of absences & total & & \\
\hline (\%) & 87.6 & 89.7 & 88.7 & & \\
\hline
\end{tabular}

${ }^{\star}$ Excellent discrimination $(>0.9)$.

†Reference category: (0-1348 m), 1st quartile.

$\ddagger$ Reference category: (0-704 m), 1st quartile.

correctly classifying $88.7 \%$ of the locations $(87.6 \%$ of presences and $89.7 \%$ of absences). The AUC was $0.95 \pm 0.01\left(P=0.00 ; \mathrm{H}_{0}: \mathrm{AUC}=0.5\right)$, which confirms the good fit of the model. In addition, the non-significant value of the Hosmer-Lemeshow test showed that the observed data were not significantly different from those predicted by the model. The study of the influences of the variables on the multivariate model measured by the Cook distance did not reveal any value $>1$. Analysis of the standardized residuals (or Pearson residuals) also attested to their distribution close to the normal (with a mean of 0 and a typical deviation of 1). Similarly, results attained on the Leverage statistics had values ranging between 0 and 0.06 . Figure 5 presents the locations of foraging adults and their probability of occurrence using the Area I model.

\section{Area II model - mixed area of lagoon, sea and salinas}

The univariate analysis selected 21 independent variables to explain Little Tern habitat selection within a mixed area of lagoon, sea and salinas (Table 2). For the Area II multivariate model the variables TERN, LAGO, DCON, DSUM and DACT were selected. Foraging Little Terns were 2.4 times more likely to be found in squares adjacent to other squares occupied by Little Terns than those that were unoccupied, and were 3.3 times more likely to be found in the lagoon than other habitats (Table 4). In the context of human activity, foraging Little Terns were more likely to be found at greater distances from human constructions, but closer to human recreational areas (beaches) and fishing areas (Table 4).

The Area II model explained moderately well the probability of occurrence of feeding Little Terns ( $G=$ $253.33, P=0.00$ ), correctly classifying $76.6 \%$ of the Little Tern locations $(75.8 \%$ of presences and $77.4 \%$ of absences). The AUC was $0.84 \pm 0.02\left(P=0.00 ; \mathrm{H}_{0}\right.$ : AUC $=0.5$ ), and the null hypothesis of no difference between observed and expected data was not rejected (Hosmer-Lemeshow test, $P=0.17$; Table 4). Finally, the influences of the variables on the multivariate model measured by the Cook distance, standardized residuals and Leverage statistics attested that the model fitted the observed data. Figure 6 presents the locations of foraging adults and their probability of occurrence using the Area II model.

\section{DIsCussion}

\section{Use of feeding habitats and feeding behaviour}

Little Tern feeding behaviour varied in a predictable manner during the breeding season: birds foraged closer to the nearest colony as the season progressed from April to June, as incubation and feeding of small chicks constrained the birds to foraging closer to 


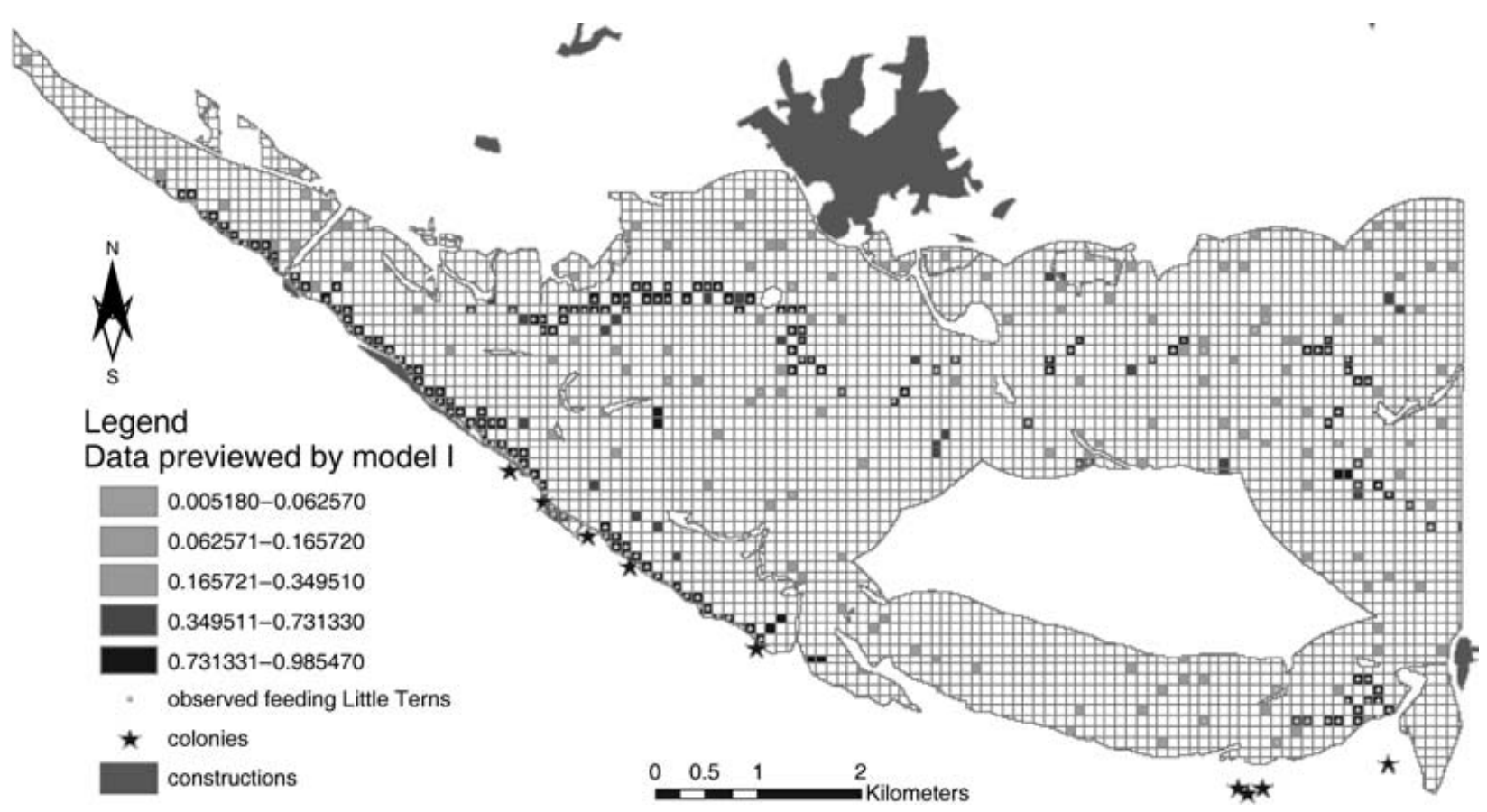

Figure 5. Spatial representation of the results for the inner lagoon habitat (Area I model). Shown are the data previewed by the model (shaded squares), observed feeding locations (white circles) and colonies (black stars) of Little Terns in 2004.

Table 4. Area II model: lagoon, salinas and adjacent sea. Coefficients $(\beta)$, standard errors (se), significance value $(P)$ and odds ratio (OR) for each selected variable are presented.

\begin{tabular}{|c|c|c|c|c|c|}
\hline Variable & $\beta \pm$ se & Wald test & $d f$ & $P$ & OR \\
\hline Foraging terns (TERN) & $0.87 \pm 0.23$ & 13.93 & 1 & 0.00 & 2.40 \\
\hline Presence of lagoon (LAGO) & $0.80 \pm 0.34$ & 5.48 & 1 & 0.02 & 2.23 \\
\hline Distance to constructions (DCON)† & & 11.81 & 3 & 0.00 & \\
\hline 654-1081 m (DCON 1) & $-0.29 \pm 0.35$ & 0.67 & 1 & 0.41 & 0.75 \\
\hline 1082-1592 m (DCON 2) & $0.65 \pm 0.41$ & 2.47 & 1 & 0.12 & 1.92 \\
\hline $1593-2850$ m (DCON 3) & $1.03 \pm 0.41$ & 6.39 & 1 & 0.01 & 2.81 \\
\hline Distance to summer recreation areas (DSUM)‡ & & 21.18 & 3 & 0.00 & \\
\hline 570-1160 m (DSUM 1) & $-0.32 \pm 0.35$ & 0.83 & 1 & 0.36 & 0.73 \\
\hline $1161-2311$ m (DSUM 2) & $-1.56 \pm 0.38$ & 16.76 & 1 & 0.00 & 0.21 \\
\hline 2312-3938 m (DSUM 3) & $-0.32 \pm 0.35$ & 0.87 & 1 & 0.35 & 0.72 \\
\hline Distance to collecting shellfish and fishing areas (DACT)§ & & 37.44 & 2 & 0.00 & \\
\hline $23-574 \mathrm{~m}(\mathrm{DACT} 1)$ & $-1.57 \pm 0.31$ & 25.99 & 1 & 0.00 & 0.21 \\
\hline 575-1711 m (DACT 2) & $-1.96 \pm 0.35$ & 30.92 & 1 & 0.00 & 0.14 \\
\hline Constant & $0.35 \pm 0.43$ & 0.66 & 1 & 0.41 & 1.42 \\
\hline Likelihood ratio test & $G=253.33, d f=9, P=0.00$ & & & & \\
\hline Area under the ROC (AUC) & Area $=0.84^{*} \pm 0.02, P=0.00$ & & & & \\
\hline Hosmer-Lemeshow test & $\chi^{2}=11.62, d f=8, P=0.17$ & & & & \\
\hline Correct classification & of presences & of absences & total & & \\
\hline (\%) ( ) & 75.8 & 77.4 & 76.6 & & \\
\hline
\end{tabular}

*Very good discrimination (0.8-0.9).

†Reference category: $(0-653 \mathrm{~m}), 1$ st quartile.

‡Reference category: (0-569 m), 1st quartile.

$\S$ Reference category: (0-22 m), 1st quartile. 


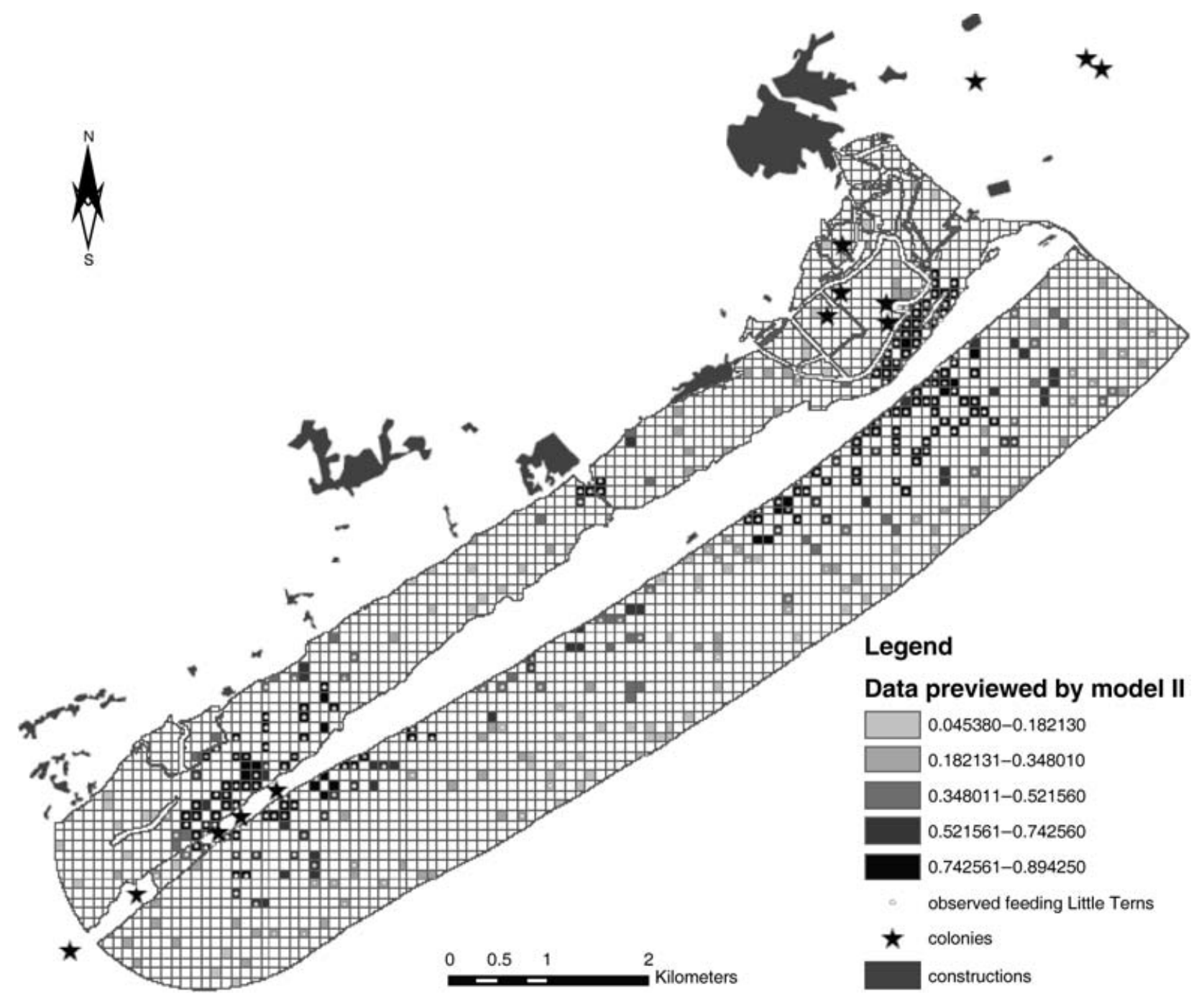

Figure 6. Spatial representation of the results for the mixed area of lagoon, salinas and adjacent sea (Area II model). Shown are the data previewed by the model (shaded squares), observed feeding locations (white circles) and colonies (black stars) of Little Terns in 2005.

colonies later in the season (Becker \& Sudmann 1992, Taylor \& Roe 2004). In July, birds again foraged further from nearest colonies as fledglings began learning how to fish. The same pattern was registered by Lyons et al. (2005) for Caspian Terns Sterna caspia breeding in the Columbia river estuary, USA.

Higher feeding activity and success in 2003 than 2004 and 2005 accords with higher colony size and reproductive success reported for that year by Medeiros et al. (2007), which in turn may be related to a higher consumption of pelagic prey in 2003 (Catry et al. 2006). Moreover, in 2003, the biomass of Sardine Sardina pilchardus, a highly energy-rich and preferred prey of Little Terns (Paiva et al. 2006a, 2006b), along the Algarve was higher than that in 2004 (IPIMAR 2005).

The sightings of birds per transect revealed that the sea (on the barrier-island of Armona; Tr5) was less used than the lagoon habitat ( $\operatorname{Tr} 8)$. In other areas, Little Tern individuals may feed over sand-banks far from the coast (up to $4 \mathrm{~km}$; Allcorn et al. 2003) when feeding resources are apparently scarce near the seashore. At Ria Formosa, the proximity of a large lagoon system with a high abundance of prey may explain the fact that the sea was less used by Little Terns. However, the greatest numbers of feeding adults were observed at sea (flocks of up to 45 individuals), which may be explained by the patchy occurrence of 
large schools of fish at the surface of the sea adjacent to the lagoon. The low but constant use of the sea for feeding during the different tidal states suggests that the availability of marine resources was independent of tide. On the other hand, the availability of prey in the lagoon to terns was apparently highly dependent on tide. Adults feed mostly on benthic fish species such as goby Pomatoschistus spp. (Catry et al. 2006), which will be available mainly during low tide. In addition, the influence of tide in the entrance channels of the lagoon, and in the main lagoon channels, was very strong and influenced the number of foraging birds. This suggests that Little Terns were relying on pelagic prey travelling along the channels during the intermediate tidal states (Neira \& Potter 1992) and that tide plays a major role in determining foraging habitat selection by estuarine foraging seabirds. There is a need to study the ecology of sand smelt Atherina spp., goby spp., Sardine and other main prey of Little Terns (Catry et al. 2006) in the seashore and in the inner lagoon of Ria Formosa, in order to gain better understanding of how environmental factors such as tide and wind speed (Paiva et al. 2006a) may influence their distribution and availability to terns in the lagoon system (Lloret et al. 2004).

\section{Foraging habitat selection and conservation implications}

The significant relationship between the occurrence of feeding Little Terns and (1) the presence of other foraging individuals, (2) the presence of lagoon feeding grounds and shellfish collecting areas, (3) the presence of main lagoon channels, and short distances to entrance channels, and (4) short distances to salinas reflects four basic needs of Little Terns for the selection of feeding areas. These are (1) the social attraction between foraging individuals, (2) the existence of areas with abundant feeding resources, (3) the existence of channels with stronger currents, which should increase the availability of prey species, and (4) the proximity of areas with alternative food sources (salinas). In general those are the main aspects that characterize the selection of foraging areas by estuarine foraging seabirds, in particular factors that promote the availability of prey species in, for example, main lagoon and entrance channels with stronger currents (Taylor 1997, Taylor \& Roe 2004, Lyons et al. 2005, this study). Finally, areas close to human constructions were avoided by Little Terns, reflecting the negative impact of strong human disturbance on foraging Little Terns (Medeiros et al. 2007).
Not surprisingly, the presence of other individuals in adjacent selected squares was selected by both models. This result is in accordance with the theory of searching and feeding in flocks, characteristic of most seabird species (Ward \& Zahavi 1973). The finding of a particularly suitable place to feed should alert other foragers to that area. The selection of areas within extensive shellfish aquaculture and harvesting of bivalves should be explained by higher prey abundance in those areas: the substrate is disturbed to collect clams, which enriches the water with nutrients, thereby increasing local productivity (Mozetic et al. 1997). The extensive culture of bivalves in estuarine lagoon systems such as Ria Formosa may in fact benefit Little Terns.

Moreover, birds that were sighted at larger distances from their colonies were observed during intermediate tidal states (receding and incoming tide), when the currents are stronger. This suggests that adults may invest more in travelling longer distances to reach areas with stronger currents. These conditions were common in the main lagoon channels and in the entrance channels, which were both selected for foraging by Little Terns, as opposed to secondary channels, where water was more settled (Taylor \& Roe 2004).

The fact that birds breeding on the barrier-island of Tavira and Santa Luzia (salinas) made little use of salinas for feeding suggests that salinas were a marginal feeding habitat for Little Terns in this area. However, proximity to salinas was of some importance in explaining the occurrence of Little Tern individuals. Prey availability should be more constant in the salinas where foraging activity is relatively unaffected by environmental factors such as wind speed (Paiva et al. 2006a), thereby increasing capture success, as shown in this study. However, prey captured in the salinas were mainly shrimps, which are of low energy value (Paiva et al. 2006a, 2006b), and have appendages which cause handling problems and may be rejected by chicks (Bogliani et al. 1994). In other areas (e.g. Aveiro lagoon, northern Portugal), Little Terns forage in salinas and adjacent channels much more regularly (Peste et al. 2004) than in Ria Formosa, presumably because they have no alternative. A similar situation is reported by Bogliani et al. (1992) for southern Italy, where shrimps were an important prey for chicks in brackish waters only. Small but intensive periods of foraging in salinas were also observed in some salinas of Ria Formosa, where the abundance of shrimp was very high (our pers. obs.). Becker et al. (1997) showed that freshwater habitats were beneficial for breeding Common Terns Sterna hirundo because prey 
availability was more stable in time and space than marine prey.

The Area II model showed that birds foraged more often in squares close to summer recreation areas, which indicates some resilience and adaptability of feeding Little Terns to relatively low levels of human disturbance. The main lagoon channels used for foraging were also the most used by small boats. Although these apparently did not affect the distribution of foraging individuals, it was evident that only a small number of Little Terns were sighted feeding in the main navigation channel, where large commercial boats enter the port of Faro. Little Terns need transparent waters to forage (Brenninkmeijer et al. 2002), which may partly explain why the main navigation channel was little used.

In summary, we were able to model, predict and map the occurrence of foraging Little Terns by using several ecological variables. This approach was important to understanding habitat use in this endangered species and highlighted the most important variables and foraging areas for Little Terns in estuarine lagoon systems.

This study is a contribution to the project POCTI/BSE/ 37385/2001 'Breeding and foraging ecology of Little Terns to provide ecological indicators in estuarine environments' financed by the Fundação Portuguesa para a Ciência e Tecnologia. We are grateful for field assistance given by Patricia Pedro and Renata Medeiros. John Bowler, Peter Becker, Jeremy Wilson and an anonymous referee made helpful comments on the manuscript.

\section{REFERENCES}

Allcorn, R., Eaton, M.A., Cranswick, P.A., Perrow, M., Hall, C., Smith, L., Reid, J., Webb, A., Smith, K.W., Langston, R.H.W. \& Ratcliffe, N. 2003. A Pilot Study of Breeding Tern Foraging Ranges in NW England and East Anglia in Relation to Potential Development Areas for Offshore Windfarms. Sandy: RSPB/ WWT/JNCC.

Ballance, L.T., Ainley, D.G. \& Hunt, G.L. 2001. Seabird Foraging Ecology. In Steele, J.H., Thorpe, S.A. \& Turekian, K.K. (eds) Encyclopedia of Ocean Sciences, Vol. 5:2636-2644. London: Academic Press.

Becker, P.H., Frank, D. \& Sudmann, S.R. 1993. Temporal and spatial pattern of common tern (Sterna hirundo) foraging in the Wadden Sea. Oecologia 93: 389-393.

Becker, P.H., Frank, D. \& Wagener, M. 1997. Luxury in freshwater and stress at sea? The foraging of the Common Tern Sterna hirundo. Ibis 139: 264-269.

Becker, P.H. \& Specht, R. 1991. Body mass fluctuations and mortality in Common Tern Sterna hirundo chicks dependent on weather and tide in the Wadden Sea. Ardea 79: 45-56.

Becker, P.H. \& Sudmann, S.R. 1992. Zeitaufwand für die Nahrungssuche von Flussseeschwalben (Sterna hirundo) während der Brut- und Huderphase. J. Ornithol. 133: 437442.

Bogliani, G., Fasola, M., Canova, L. \& Saino, N. 1992. Foraging rhythm and chick diet in little terns in three Adriatic coastal wetlands. Avocetta 16: 31-34.

Bogliani, G., Fasola, M., Canova, L. \& Saino, N. 1994. Prey selection by parents and chicks of the Little Tern Sterna albifrons. Avocetta 18: 9-11.

Brenninkmeijer, A., Stienen, E.W.M., Klaassent, M. \& Kersten, M. 2002. Foraging ecology of wintering terns in Guinea-Bissau. Ibis 144: 602-613.

Burger, J. \& Lesser, F. 1978. Selection of colony sites and nest sites by Common Terns Sterna hirundo in Ocean County, New Jersey. Ibis 120: 433-449.

Catry, T., Ramos, J.A., Catry, I., Revez, M.-A. \& Grade, N. 2004. Are salinas a suitable alternative breeding habitat for Little Terns? Ibis 146: 247-257.

Catry, T., Ramos, J.A., Martins, J., Peste, F., Trigo, S., Paiva, V.H., Almeida, A., Luís, A., Palma, J. \& Andrade, P. 2006. Intercolony and annual differences in the diet and feeding ecology of Little Tern adults and chicks in Portugal. Condor 108: 366-376.

Cramp, S. \& Simmons, K.E.L. (eds) 1983. The Birds of the Western Palearctic, Vol. 4. Oxford: Oxford University Press.

Dunn, E.K. 1973. Changes in fishing ability of terns associated with windspeed and sea surface conditions. Nature 244: 520-521.

Dytham, C. 2003. Choosing and Using Statistics: a Biologist's Guide. Oxford: Blackwell Publishing.

Erwin, R.M. 1978. Coloniality in terns: the role of social feeding. Condor 80: 211-215.

ESRI. 2004. Arcview GIS V9.0. Redlands, CA: Environmental Systems Research Institute.

Fasola, M. \& Bogliani, G. 1990. Foraging ranges of an assemblage of mediterranean seabirds. Colon. Waterbirds 13: $72-74$.

Field, A. 2000. Discovering Statistics Using SPSS for Windows. London: Sage Publications.

Franco, A., Brito, J.C. \& Almeida, J. 2000. Modelling habitat selection of Common Cranes Grus grus wintering in Portugal using multiple logistic regression. Ibis 142: 351-358.

Franco, A. \& Sutherland, W. 2004. Modelling the foraging habitat selection of lesser kestrels: conservation implications of European Agricultural Policies. Biol. Conserv. 120: 6374.

Frank, D. 1992. The influence of feeding conditions and food provisioning of chicks in Common Terns Sterna hirundo nesting in the German Wadden Sea. Ardea 80: 45-55.

Frank, D. \& Becker, P.H. 1992. Body mass and nest reliefs in Common Terns Sterna hirundo exposed to different feeding conditions. Ardea $\mathbf{8 0}$ (special issue): 57-69.

Fraser, G. 1997. Feeding ecology of Forster's Terns on Lake Osakis, Minnesota. Colon. Waterbirds 20: 87-94.

Garthe, S. 1997. Influence of hydrography, fishing activity, and colony location on summer seabird distribution in the southeastern North Sea. ICES J. Mar. Sci. 54: 566-577.

Hosmer, D. \& Lemeshow, S. 2000. Applied Logistic Regression. New York: John Wiley \& Sons.

Huettmann, F. \& Diamond, A.W. 2001. Seabird colony locations and environmental determination of seabird distribution: a spatially explicit breeding seabird model for the Northwest Atlantic. Ecol. Model. 141: 261-298. 
Hulsman, K. 1977. Feeding and Breeding Biology of Six Sympatric Species of Tern (Laridae) at One Tree Island, Great Barrier Reef. PhD Thesis, University of Queensland.

Hulsman, K., Langham, N.P.E. \& Blühdorn, D. 1989. Factors affecting the diet of Crested Terns, Sterna bergii. Aust. Wild. Res. 16: 475-489.

Hunt, G.L. Jr 1997. Physics, zooplankton, and the distribution of least auklets in the Bering Sea - a review. ICES J. Mar. Sci. 54: 600-607.

IPIMAR. 2005. Report from an Acoustic Sardine Sardina pilchardus Detection Campaign on the Portuguese Coast - November 2005. Institutional report. Lisbon.

Jenness. 2005a. Random point generator (randpts.avx) extension for ArcView 3.x, v. 1.3. Arizona: Jenness Enterprises.

Jenness. 2005b. Nearest features (nearfeat.avx) extension for ArcView 3.x, v. 3.8a. Arizona: Jenness Enterprises.

Jones, J. 2001. Habitat selection studies in avian ecology: a critical review. Auk 118: 557-562.

Kotliar, N.B. \& Burger, J. 1986. Colony site selection and abandonment by Least Terns Sterna antillarum in New Jersey, USA. Biol. Conserv. 37: 1-21.

Krogh, M.G. \& Schweitzer, S.H. 1999. Least Terns nesting on natural and artificial habitats in Georgia, USA. Waterbirds 22: $290-296$

Lloret, J., Palomera, I., Salat, J. \& Sole, I. 2004. Impact of freshwater input and wind on landings of anchovy (Engraulis encrasicolus) and sardine (Sardina pilchardus) in shelf waters surrounding the Ebre (Ebro) River delta (north-western Mediterranean). Fish. Oceanogr. 13: 102-110.

Lyons, D.E., Roby, D.D. \& Collis, K. 2005. Foraging ecology of Caspian Terns in the Columbia River estuary, USA. Waterbirds 28: 280-291.

Manel, S., Williams, H. \& Ormerod, S. 2001. Evaluating presenceabsence models in ecology: the need to account for prevalence. J. Appl. Ecol. 38: 921-931.

McGinnis, T.W. \& Emslie, S.D. 2001. The foraging ecology of Royal and Sandwich Terns in North Carolina, USA. Waterbirds 24: $361-370$

Medeiros, R., Ramos, J.A., Paiva, V.H., Almeida, A., Pedro, P. \& Antunes, S. 2007. Signage reduces the impact of disturbance on Little Tern nesting success in Portugal. Biol. Conserv. 135: 99-106.

Montevecchi, W.A. \& Myers, R.A. 1996. Dietary changes of seabirds indicate shifts in pelagic food webs. Sarcia 80:313322.

Mozetic, P., Turk, V., Malej, A., Terzic, S., Ahel, M. \& Cauwet, G. 1997. Coastal plankton response to nutrient enrichment: an experimental system. In Water Pollution IV. Modelling, Measuring and Prediction. Rajar, R. \& Brebbia, C.A. (eds), Computational Mechanics Publs., Southampton, Boston, pp. $151-160$

Neira, F.J. \& Potter, I.C. 1992. Movement of larval fishes through the entrance channel of a seasonally open estuary in Western Australia. Est. Coast. Shelf Sci. 35: 213-224.

Nisbet, I.C.T. 2002. Common Tern (Sterna hirundo). In Poole, A. \& Gill, F. (eds) The Birds of North America, No. 618. Philadelphia, PA: Academy of Natural Sciences; Washington, DC: American Ornithologists' Union.

Osborne, P.E., Alonso, J.C. \& Bryant, R.G. 2001. Modelling landscape-scale habitat use using GIS and remote sensing: a case study with great bustards. J. Appl. Ecol. 38: 458471.
Paiva, V.H., Ramos, J.A., Catry, T., Pedro, P., Medeiros, R. \& Palma, J. 2006a. Influence of environmental factors and energetic value of food on Little Tern chick growth and food delivery. Bird Study 53: 1-11

Paiva, V.H., Ramos, J.A., Machado, D., Penha-Lopes, G., Bouslama, M.F., Dias, N. \& Nielsen, S. 2006b. Importance of marine prey to growth of estuarine tern chicks: evidence from an energetic balance model. Ardea 94: 241-255.

Pardo, A. \& Ruiz, M.A. (eds) 2002. SPSS 11-Guía Para el Análisis de Datos. Madrid: McGraw-Hill.

Peste, F., Trigo, S. \& Luís, A. 2004. Foraging behaviour of breeding Little Tern Sterna albifrons at Ria de Aveiro. Airo 14 55-62.

Pinilla, J.S. 2002. Cartografia predictiva de la distribución de aves terrestres: un estudio piloto en Andalucía occidental. PhD Thesis, Universidad Autónoma de Madrid.

Ramos, J.A. 1998. Nest site selection by Roseate Terns breeding on Aride Island, Seychelles. Colon. Waterbirds 21: 438-443.

Ramos, J.A. \& del Nevo, A.J. 1995. Nest site selection by Roseate Terns and Common Terns in the Azores. Auk 112: $580-589$.

Ramos, J.A., Sola, E., Monteiro, L.R. \& Ratcliffe, N. 1998. Prey delivered to Roseate Tern chicks in the Azores. J. Field Ornithol. 69: 419-429.

Schneider, D.C. 1991. The role of fluid dynamics in the ecology of marine birds. Oceanogr. Mar. Biol. Ann. Rev. 29: 487-521.

Smith, G.C. 1990. Factors influencing egg laying and feeding in Black-naped Terns Sterna sumatrana. Emu 90: 88-96.

Smith, J.W. \& Renken, R.B. 1991. Least Tern nesting habitat in the Mississippi river valley adjacent to Missouri. J. Field Ornithol. 62: 497-504.

Stienen, E., Beers, P., Brenninkmeijer, A., Habraken, J., Raaijmakers, M. \& Van Tienen, P. 2000. Reflections of a specialist: patterns in food provisioning and foraging conditions in Sandwich Terns Sterna sandvicensis. Ardea 88: 33-49.

Tabachnick, B. \& Fidell, L. 1996. Using Multivariate Statistics. New York: HarperCollins.

Taylor, I.R. 1997. The foraging ecology of Common and Sandwich Terns on the Ythan Estuary. In Gorman, M. (ed.) The Ythan: 106-116. Aberdeen: University of Aberdeen.

Taylor, I.R. \& Roe, E.L. 2004. Feeding ecology of little terns Sterna albifrons sinensis in south-easthern Australia and the effects of pilchard mass mortality on breeding success and population size. Mar. Freshwater Res. 55: 799-808.

Vlietstra, L.S., Coyle, K.O., Kachel, N.B. \& Hunt, G.L. 2005. Tidal front affects the size of prey used by a top marine predator, the short-tailed shearwater (Puffinus tenuirostris). Fish. Oceanogr. 14: 196-211.

Ward, P. \& Zahavi, A. 1973. The importance of certain assemblages of birds as 'information-centres' for food-finding. Ibis 115: 517-534.

Wendeln, H. 1997. Allocation of parental duties and foraging behaviour influence body condition of adult Common Terns, Sterna hirundo. Bird Behav. 12: 47-54.

Zar, J.H. 1999. Biostatistical Analysis. New Jersey: Prentice Hall.

Zweig, M.H. \& Campbell, G. 1993. Receiver-operating characteristic (ROC) plots: a fundamental evaluation tool in clinical medicine. Clin. Chemis. 39: 561-577.

Received 16 May 2006; revision accepted 17 April 2007. 